\title{
PENGARUH POLA ASUH ORANG TUA DAN TEMAN SEBAYA TERHADAP ASERTIFITAS REMAJA DALAM PERILAKU SEKSUAL DI SMP NEGERI I HINAI KECAMATAN HINAI KABUPATEN LANGKAT TAHUN 2014
}

\author{
Wardati Humaira \\ Jurusan Kebidanan Poltekkes Medan
}

\begin{abstract}
Abstrak
Berbagai upaya pembangunan untuk menggali potensi remaja dilakukan, sehingga menyebabkan perubahan pada kehidupan remaja. Apabila upaya pembangunan yang dilakukan seimbang dan proporsional tentu tidak akan menimbulkan masalah yang cukup berarti, akan tetapi adanya ketidakseimbangan upaya pembangunan yang dilakukan terutama terhadap remaja, akhirnya menimbulkan masalah bagi pembangunan itu sendiri. Salah satu masalahnya adalah terjadinya perubahan mendasar yang menyangkut sikap dan perilaku seksual pranikah di kalangan remaja (Notoatmodjo, 2007). Penelitian ini bertujuan untuk mengetahui pengaruh faktor asertifitas remaja dalam perilaku seksual di SMP Negeri 1 Hinai Kabupaten Langkat Tahun 2013. Penelitian ini merupakan penelitian kuantitatif dengan menggunakan metode survei explanatory research. Populasi dalam penelitian ini adalah seluruh siswi SMP Negeri 1 Hinai yang berjumlah 363 orang. Sampel pada penelitian ini adalah siswi kelas VIII dan IX sebanyak 113 orang, dengan pengambilan sampel menggunakan proportional random sampling. Pengumpulan data diperoleh melalui penyebaran angket menggunakan alat bantu kuesioner, dianalisis dengan regresi logistik berganda pada $\alpha=5 \%$. Hasil penelitian ini menunjukkan, asertifitas remaja dalam perilaku seksual berada pada kategori tinggi $(57,5 \%)$, dan secara statistik variabel yang paling dominan memengaruhi adalah teman sebaya yaitu dengan nilai koefisien regresi 5,011. Disarankan pihak sekolah SMP Negeri 1 Hinai hendaknya meningkatkan perilaku asertif remaja dengan memasukkan pendidikan asertif dalam kurikulum muatan lokal di sekolah dan dapat bekerja sama dengan orang tua remaja dalam mengontrol hubungan remaja dengan teman sebaya, pihak terkait mengajarkan remaja untuk lebih berani dalam pengambilan keputusan, responden harus dapat mempertahankan harga diri.
\end{abstract}

Kata kunci : Asertifitas, Perilaku Seksual

\section{PENDAHULUAN}

Salah satu dampak dari Total Fertility Rate (TFR) dan Infant Mortality Rate (IMR) adalah perubahan struktur umur penduduk, diantaranya yaitu terjadinya peningkatan jumlah penduduk usia remaja. Berdasarkan data BPS, 2011, jumlah pemuda Indonesia (penduduk berusia 16 - 30 tahun) diperkirakan sebanyak 51,95 juta jiwa atau 25,69\% dari penduduk Indonesia yang berjumlah 241,13 juta jiwa. Dari data tersebut diketahui kelompok umur pemuda yang berusia 16 - 20 tahun sebesar 32,06\%. Jumlah remaja yang tidak sedikit ini merupakan potensi yang sangat berarti dalam melanjutkan pembangunan di Indonesia.

Kesehatan Reproduksi Remaja (KRR) dalam Rencana Pembangunan Jangka Menengah Nasional 2004 2009, merupakan salah satu dari program pemerintah dalam sektor pembangunan sumber daya manusia. Sasaran dari program ini adalah untuk meningkatkan pengetahuan, sikap dan perubahan prilaku remaja melalui pelayanan dan informasi kesehatan reproduksi (Bappenas, 2007).
Perilaku seksual yang melanda remaja ini cenderung meningkat. Akibat dari segala dampak yang muncul seperti kehamilan di luar nikah, kawin muda, anakanak lahir diluar nikah, aborsi, penyakit menular seksual, depresi pada wanita yang terlanjur berhubungan seks dan lain sebagainya (Sarwono, 2012).

Berdasarkan laporan WHO (2012), pada tahun 2008, ada 16 juta kelahiran dari ibu yang berusia 15-19 tahun, yang mewakili $11 \%$ dari seluruh kelahiran yang ada di dunia. Sekitar 95\% dari kelahiran terjadi di negara berpenghasilan rendah dan menengah. Angka kelahiran global remaja ini telah menurun dari 60 per 1000 pada tahun 1990 menjadi 48 per 1000 pada tahun 2007, yang diawali dari 5 per 1000 wanita di Asia Timur menjadi 121 per 1000 di sub-Sahara Afrika pada tahun 2007. The World Bank (2010), juga mencatat laporan dari Millennium Development Goals (MDGs) (2010), dimana tingkat kelahiran remaja usia 15 - 19 tahun adalah 53 per 1000 kelahiran.

Berbagai data yang berkaitan dengan perilaku seksual remaja secara global sudah sangat mengkhawatirkan. Menurut data dari The National Survey 
of Family Growth (2011), yang mencatat aktivitas seksual, penggunaan kontrasepsi, kelahiran selama tahun 20062010, sekitar $43 \%$ remaja perempuan (4,4 juta), dan sekitar $42 \%$ remaja laki-laki (4,5 juta) telah melakukan hubungan seksual pra nikah setidaknya sekali. $78 \%$ perempuan dan $85 \%$ laki-laki menggunakan metode kontrasepsi pada seks pertama.

Menurut data BPS, BKKBN, DEPKES RI, dan Macro Internasional, 2008, yang mencatat Indonesian Young Adult Reproductive Health Survey (IYARHS) tahun 2007, ditemukan $1 \%$ wanita pernah melakukan hubungan seksual sedangkan pria $6 \%$. Beberapa responden ditanya alasan melakukan hubungan seksual pertama mereka. Keingintahuan tampaknya menjadi alasan utama untuk berhubungan seks yaitu 45\%, dan laki-laki lebih mungkin dibandingkan perempuan untuk menyebutkan alasan ini yaitu masing-masing sebanyak $51 \%$ dan $7 \%$.

Berdasarkan survei yang telah dilakukan di SMP (Sekolah Menengah Pertama) Negeri I Hinai, diperoleh hasil pada satu kelas yang berisikan 32 siswa terdapat 18 siswa yang mengaku sudah pernah pacaran dan mulai berpacaran pada umur 14 tahun. Tetapi para siswa mengaku gaya berpacarannya masih dalam batas berpegangan tangan $90 \%$, berciuman bibir $75 \%$.

Remaja perlu keterampilan dalam menghadapi transisi kehidupannya untuk menjadi dewasa. sehingga dalam melewati masa remaja menuju dewasa, remaja dapat bertahan menghadapi tantangan, hambatan, serta dapat memanfaatkan peluang yang ada dihadapannya. Santrock (2007) mengutip pendapat Scheer dan Unger (1994), bahwa bertanggung jawab pada diri sendiri dan mengambil keputusan secara mandiri merupakan hal yang penting untuk mencapai status dewasa.

Myers dan Myers (2002) mengatakan asertifitas adalah salah satu gaya komunikasi dimana individu dapat mempertahankan hak dan mengekspresikan perasaan, pikiran dan kebutuhan secara langsung, jujur dan bersikap terus terang.Asertif untuk kelompok remaja sangat diperlukan dalam menghadapi tekanan sebaya. Tekanan itu berkaitan dengan ajakan untuk terlibat kedalam resiko Triad KRR yaitu Seksualitas, HIV/AIDS dan Napza.

Rakos (1991) mengemukakan bahwa konsep asertifitas berkaitan dengan kebudayaan dimana seseorang tumbuh dan berkembang. Dapat dikatakan bahwa pada suatu budaya suatu prilaku dipandang asertif dan sesuai dengan budaya setempat. Akan tetapi hal yang sama tidak dapat ditolerir oleh masyarakat dengan latar belakang budaya lain.

Marini dkk (2005), mengutip pendapat Hawari dkk (2002), menyatakan bahwa penyebab para remaja terjerumus ke hal yang negatif seperti seks bebas, salah satunya adalah karena kepribadian yang lemah. Ciri cirinya antara lain daya tahan terhadap tegangan dan tekanan rendah, kurang bisa mengekpresikan diri, kurang bisa mengendalikan emosi dan agresivitas serta tidak dapat mengatasi masalah dan konflik dengan baik yang erat kaitannya dengan asertivitas.

Rosita (2010) dan Hidayah (2010) yang mengutip pendapat Rathus dan Nevid (1983) mengatakan bahwa faktor-faktor yang mempengaruhi asertifitas, yaitu jenis kelamin, usia, budaya, tingkat pendidikan, harga diri (self esteem), dan situasi tertentu lingkungan sekitarnya seperti pola asuh orang tua dan teman sebaya.

Menurut Hidayah (2010) yang mengutip pendapat Daud (2004), komunikasi orang tua dan anak dapat memengaruhi kemampuan anak untuk mengungkapkan pikiran dan perasaannya. Berbedanya pola asuh yang diberikan orang tua dapat mengakibatkan berbedanya tingkat asertifitas anak.

Menurut Albert (2012) yang mencatat hasil survey yang dilakukan oleh The National Campaign (2012), remaja mengatakan bahwa orangtua paling besar memengaruhi keputusan mereka tentang seks, lebih daripada teman sebaya, budaya, guru dan lain-lain, diperoleh hasil 4 dari 10 remaja (38\%) mengatakan orang tua paling memengaruhi keputusan mereka tentang seks, dibandingkan dengan $22 \%$ yang dipengaruhi oleh temanteman.

Sikap Asertif untuk kelompok remaja sangat diperlukan dalam menghadapi tekanan remaja sebaya. Tekanan itu berkaitan dengan ajakan untuk terlibat kedalam risiko triad KRR, yaitu seksualitas, HIV/AIDS dan napza. Menurut Suwarni (2009), bahwa pengaruh perilaku seksual teman sebaya secara langsung paling besar memengaruhi perilaku seksual remaja. Pengaruh perilaku seksual teman sebaya secara langsung sebesar $20,2 \%$, sedangkan pengaruh perilaku seksual teman sebaya secara tidak langsung melalui niat berperilaku seksual sebesar $14,24 \%$.

Berdasarkan beberapa uraian tentang perilaku seksual dan pentingnya asertifitas pada perilaku seksual remaja serta adanya faktor-faktor yang dapat memengaruhi asertifitas tersebut, maka akan dilakukan penelitian mengenai pengaruh factor pola asuh, dan teman sebaya terhadap asertivitas pada perilaku seksual di SMP Negeri 1 Hinai Kabupaten Langkat Tahun 2013.

\section{METODE PENELITIAN}

Jenis penelitian ini merupakan penelitian kuantitatif explanatory research. Penelitian ini menggunakan pendekatan cross sectional.

Penelitian ini dilakukan di SMP Negeri 1 Hinai Kecamatan Hinai Kabupaten Langkat. Populasi dalam penelitian ini adalah seluruh siswi SMP Negeri 1 Hinai yang berjumlah 363 orang. Sampel dalam penelitian ini adalah siswi kelas VIII dan kelas IX SMP Negeri 1 Hinai, yang dinyatakan masih terdaftar dan dan aktif bersekolah di SMP tersebut. Sampel pada penelitian ini adalah 113 orang, dengan pengambilan sampel menggunakan proportional random sampling.

Pengumpulan data melalui data primer dan data sekunder. Data primer diperoleh secara langsung dari responden melalui penyebaran angket menggunakan alat bantu kuesioner.

Data sekunder diperoleh dari data demografi Kecamatan Hinai Kabupaten Langkat, data Puskesmas Tanjung Beringin, Profil Dinas Kesehatan Kabupaten Langkat, data Badan Pusat Statistik Kabupaten Langkat, data Operasional pelaksanaan BP-4 Kecamatan Hinai Kabupaten Langkat, dan data dari SMP Negeri 1 Hinai. 
Data yang telah dikumpulkan akan dilakukan analisis dengan menggunakan analisa univariat, dan analisis bivariat menggunakan uji Chi-square serta analisis multivariat menggunakan uji regresi logistik ganda (multiple logistic regression) masing - masing pada tingkat kepercayaan $95 \%(\alpha=0,05)$.

\section{HASIL DAN PEMBAHASAN}

\section{Univariat}

Berdasarkan karakteristik mayoritas umur responden berada pada rentang umur 13 - 15 tahun yaitu sebanyak 89 orang $(78,8 \%)$, diketahui pula suku mayoritas responden adalah Jawa yaitu sebanyak 62 orang (54,9\%), dan mayoritas responden memeluk agama Islam yaitu sebanyak 91 orang $(80,5 \%)$.

Selanjutnya hasil univariat berdasarkan asertifitas dalam perilaku seksual, pola asuh dan teman sebaya dapat dilihat padat Tabel 1 dan 2 berikut :

Tabel 1. Karakteristik Responden berdasarkan Asertifitas dalam Perilaku Seksual

\begin{tabular}{lcccc}
\hline & Variabel & \multicolumn{1}{c}{ f } & \% \\
\hline Asertifitas & dalam & Perilaku & & \\
Seksual & & & & \\
Tinggi & & 65 & 57,5 \\
Rendah & & 48 & 42,5 \\
\hline
\end{tabular}

Tabel 2. Karakteristik Responden berdasarkan Pola Asuh, dan Teman Sebaya

\begin{tabular}{llll}
\hline \multicolumn{1}{c}{ Variabel } & \multicolumn{1}{c}{ f } & \% \\
\hline Pola Asuh & & & \\
Otoriter & 19 & 16,8 \\
Permisif & 7 & 6,2 \\
Demokratis & 87 & 77,0 \\
Teman Sebaya & & \\
Baik & 68 & 60,2 \\
Buruk & 45 & 39,8 \\
\hline
\end{tabular}

\section{Bivariat}

Uji statistik yang digunakan adalah uji chi-square pada tingkat kemaknaan $\alpha<0,05$.

Hasil analisis bivariat diketahui bahwa variabel yang berpengaruh terhadap asertifitas adalah teman sebaya nilai $p=0,001$. Secara rinci hasil bivariat dapat dilihat pada Tabel 4.

Tabel 4. Pengaruh Variabel Independen ( Pola Asuh dan Teman Sebaya) Terhadap Asertifitas dalam Perilaku Seksual

\begin{tabular}{|c|c|c|c|c|c|c|c|}
\hline \multirow[t]{3}{*}{$\begin{array}{c}\text { Variabel } \\
\text { Independen }\end{array}$} & \multicolumn{3}{|c|}{$\begin{array}{l}\text { Asertivitas dalam } \\
\text { Perilaku Seksual }\end{array}$} & \multirow{2}{*}{\multicolumn{2}{|c|}{ Total }} & \multirow[t]{3}{*}{$P$} & \multirow[t]{3}{*}{$\chi^{2}$} \\
\hline & \multicolumn{2}{|c|}{ Tinggi } & Rendah & & & & \\
\hline & f & $\%$ & $\%$ & f & $\%$ & & \\
\hline \multicolumn{8}{|l|}{ Pola Asuh } \\
\hline Otoriter & 11 & 57,98 & 42,1 & 19 & 100,0 & 0,275 & 2,582 \\
\hline Permisif & 2 & 28,65 & 71,4 & 7 & 100,0 & & \\
\hline Demokratis & 52 & 59,835 & 40,2 & 87 & 100,0 & & \\
\hline \multicolumn{8}{|l|}{ Teman } \\
\hline Sebaya & 50 & 73,518 & 26,5 & 68 & 100,0 & 0,001 & 17,907 \\
\hline $\begin{array}{l}\text { Baik } \\
\text { Buruk }\end{array}$ & 15 & 33,330 & 66,7 & 45 & 100,0 & & \\
\hline
\end{tabular}

\section{Analisis Multivariat}

Analisis multivariat dilakukan untuk menganalisis pengaruh variabel independen (pola asuh dan teman sebaya terhadap variabel dependen (asertifitas dalam perilaku seksual) siswi SMP Negeri 1 Hinai dengan menggunakan analisis regresi logistik berganda.

Sebelumnya dilakukan pemeriksaan kolinearitas antar semua variabel independen yang masuk dalam kandidat model multivariat, dan dilakukan pemeriksaan interaksi pada alternatif model yang terpilih. Model akhir dari analisis multivariat yang dapat dilihat pada Tabel 5.

Tabel 5. Hasil Analisis Regresi Logistik

\begin{tabular}{llcccc}
\hline \multirow{2}{*}{ Variabel } & \multirow{2}{*}{$\mathbf{B}$} & $\boldsymbol{P}$ & $\begin{array}{c}\text { Exp } \\
\text { (B) }\end{array}$ & \multicolumn{2}{c}{ 95\% CI } \\
\hline Temansebaya & 1,139 & 0,001 & 5,011 & 2,094 & 11,988 \\
Constant & - & 0,001 & 0,173 & & \\
& 1,754 & & & & \\
\hline
\end{tabular}

\section{Asertifitas dalam Perilaku Seksual}

Sikap asertif dalam perilaku seksual telah dikembangkan untuk lebih memahami komunikasi perempuan dalam upaya melindungi hak-hak seksualitasnya, hal ini didasarkan pada asumsi bahwa perempuan memiliki hak atas tubuh mereka sendiri. Seorang remaja harus memiliki kemampuan untuk berkomunikasi secara efektif dalam perilaku seksual, hal ini sangat penting untuk melindungi dirinya terhadap perilaku seksual yang tidak diinginkan.

Hidayah (2010) yang mengutip pendapat Getlin et al (2009), mengemukakan bahwa faktor signifikan yang mengarah ke situasi seksual negatif adalah kurangnya komunikasi asertif dapat menjadi masalah bagi berbagai alasan, termasuk menyebabkan penyesalan dari hubungan seksual, tertular infeksi menular seksual, dan mengalami situasi seksual paksaan. Situasi-situasi ini dapat mengakibatkan berbagai tingkat kesulitan, mulai dari kecemasan dan rendah diri sampai berkurangnya prestasi akademik remaja apabila hal ini terjadi pada remaja awal.

Menurut Brown dkk (2009), asertif adalah kemampuan berkomunikasi yang meliputi berbagi perasaan yang positif, mengapresiasikan kehangatan, mampu mengungkapkan perasaan dari ketidaknyamanan, mengatur batasan, dan berkata tidak pada orang lain yang berupaya mempengaruhi keinginan dan keyakinan diri kita.

Muadz dan Syaefuddin (2010) mendefinisikan asertif adalah sebuah sikap untuk mengekspresikan diri secara tegas kepada pihak lain tanpa harus menyakiti pihak lain ataupun merendahkan diri di hadapan pihak lain. Bersikap tegas adalah sebuah cara khusus yang dapat dipelajari dan dipraktekkan. Sikap tegas membuat seseorang mampu menyatakan pikiran, perasaan dan nilainilai mengenai sesuatu secara terbuka dan langsung, dengan tetap menghormati perasaan dan nilai - nilai pihak lain. Bersikap tegas adalah salah satu perilaku yang dapat dipilih ketika seseorang berada dalam situasi yang sulit dan ketika harus mengambil sebuah keputusan. Keterampilan ini meningkatkan kemungkinan seseorang menghadapi sebuah situasi sulit tanpa kehilangan harga diri atau martabatnya. 
Rosita (2011) yang mengutip pendapat Rathus dan Nevid (1983), bahwa faktor yang memengaruhi asertifitas, terdiri dari usia, jenis kelamin, harga diri (self esteem), budaya, tingkat pendidikan serta situasi yang ada di sekitar seperti pola asuh orang tua dan teman sebaya. Selanjutnya perilaku asertif yang diteliti adalah perilaku asertif dalam perilaku seksual, oleh karena itu beberapa faktor yang memengaruhi perilaku seksual juga menjadi bagian yang akan diteliti.

\section{Pola Asuh}

Dalam penelitian ini, pola asuh orang tua responden sebagian besar adalah demokratis yaitu $77,7 \%$. Berdasarkan analisis bivariat diperoleh hasil bahwa dari 65 orang responden yang asertivitas dalam perilaku seksual tinggi terdapat $59,8 \%$ yang pola asuhnya demokratis. Terdapat 40,2\% responden dengan asertivitas dalam perilaku seksual rendah tetapi juga memiliki orang tua dengan pola asuh demokratis. Hasil uji statistik menunjukkan nilai $p=0,275$ artinya tidak ada pengaruh yang signifikan antara pola asuh orang tua terhadap asertivitas dalam perilaku seksual.

Hal ini tidak sejalan dengan penelitian Marini dan Andriani (2005), bahwa subjek dengan pola asuh authoritative atau otoriter memiliki asertivitas lebih tinggi dibandingkan dengan subjek dengan pola asuh authoritarian (demokratis) ataupun permissive (permisif).

Hal ini juga bertolak belakang dengan hasil penelitian Titanida (2008) yang meneliti hubungan pola asuh demokratis orangtua dengan tingkat asertivitas remaja yang menunjukkan hasil uji linearitas antara pola asuh demokratis orangtua dan tingkat asertivitas pada remaja dengan probabilitas $0,001(\mathrm{p}<0,05)$ yang berarti hasil dari uji linearitas dari pola asuh demokratis orangtua dan tingkat asertivitas bersifat linear yaitu ada hubungan positif antara pola asuh demokratis dengan tingkat asertivitas remaja.

Asrori (2010) yang mengutip pendapat Covey (1989), teori determinasi yang diterima secara luas untuk menjelaskan sikap manusia, yaitu determinasi psikis (psychic determinism) yang berpandangan bahwa sikap individu merupakan hasil dari perlakuan, pola asuh, atau pendidikan orangtua yang diberikan pada anaknya.

Hasil penelitian ini memang menjelaskan bahwa tidak ada pengaruh pola asuh orang tua terhadap asertifitas remaja, hal ini dapat diasumsikan bahwa dalam berperilaku seseorang akan melihat kondisi dan situasi dalam arti luas, salah satunya adalah kedekatan remaja dengan teman sebaya, responden dalam penelitian ini ada kecendrungan lebih dekat dengan teman, dan teman yang dimiliki adalah teman yang dapat mengarahkan kearah yang baik.

Hasil tabulasi silang antara pola asuh dan teman sebaya menjelaskan bahwa adanya teman sebaya yang baik mengurangi pengaruh pola asuh orang tua, sehingga walaupun pola asuh orang tua paling tinggi adalah demokratis, tetapi teman sebaya memiliki pengaruh lebih besar terhadap tingginya asertivitas dalam perilaku seksual pada responden.

Hal ini sejalan dengan pernyataan Ristianti (2012) mengutip pendapat Desmita (2005), mengatakan meskipun remaja masih bergantung pada orang tuanya, namun intensitas ketergantungan tersebut telah berkurang dan remaja mulai mendekatkan diri pada teman-teman yang memiliki rentang usia yang sebaya dengan dirinya. Remaja mulai belajar mengekspresikan perasaan-perasaan dengan cara yang lebih matang dan berusaha memperoleh kebebasan emosional dengan cara menggabungkan diri dengan teman sebayanya.

Berdasarkan profil Kecamatan Hinai (2011), mayoritas penduduk Kecamatan Hinai memiliki mata pencaharian sebagai petani yaitu $63 \%$ dari 47.843 penduduk yang ada. Sebagai petani yang bekerja seharian di sawah, cenderung akan sangat sulit memberi perhatian yang optimal kepada anak-anaknya, walaupun secara pengasuhan orang tua tetap memantau perkembangan anak, tetapi banyaknya waktu yang dihabiskan bersama dalam keluarga juga turut mendukung pola kedekatan anak dan orang tuanya.

Menurut Ali dan Asrori (2011), dalam proses perkembangan sosial, anak juga dengan sendirinya mempelajari proses penyesuaian diri. Selain di lingkungan keluarga, ligkungan sekolah juga memberikan bantuan bagi remaja untuk memiliki keterampilan mengatasi masalah yang dihadapi. Para guru dan teman-teman sekelas membentuk suatu sistem yang kemudian menjadi semacam norma bagi diri remaja. Jika salah satu kelompok lebih kuat dari lainnya, anak akan menyesuaikan dirinya dengan kelompok dimana dirinya dapat diterima dengan baik. Hal inilah yang juga dapat menyebabkan mengapa pola asuh tidak memberikan pengaruh terhadap asertifitas remaja di SMP Negeri 1 Hinai.

\section{Teman Sebaya}

Pengaruh teman sebaya terhadap asertivitas dalam perilaku seksual didapat bahwa dari 68 orang responden yang memiliki teman sebaya baik terdapat $73,5 \%$ yang asertivitas dalam perilaku seksual tinggi. Terdapat 33,3\% responden yang memiliki teman sebaya yang buruk tetapi memiliki asertivitas dalam perilaku seksual yang tinggi. Hasil uji statistik menunjukkan nilai $p$ $=0,001$ artinya ada pengaruh yang signifikan antara teman sebaya terhadap asertivitas dalam perilaku seksual.

Menurut analisis multivariat terdapat pengaruh yang signifikan teman sebaya terhadap asertivitas dalam perilaku seksual dengan nilai $p=0,001<\alpha=0,05$ dan OR 5,011 dengan 95\% CI=2,09-11,99. Hal ini dapat diartikan bahwa kemungkinan responden yang memiliki teman sebaya baik memiliki asertivitas dalam perilaku seksual 5,01 kali lebih tinggi dibanding responden dengan kelompok responden yang memiliki teman sebaya kurang baik

Teman sebaya atau peers adalah anak-anak dengan tingkat kematangan atau usia yang kurang lebih sama. Salah satu fungsi terpenting dari kelompok teman sebaya adalah untuk memberikan sumber informasi dan komparasi tentang dunia di luar keluarga. Meskipun demikian perkembangan anak juga sangat dipengaruhi oleh apa yang terjadi dalam konteks sosial yang lain seperti relasi dengan teman sebaya. 
Suwarjo (2008) mengutip pendapat Laursen (2005) menandaskan bahwa teman sebaya merupakan faktor yang sangat berpengaruh terhadap kehidupan pada masa-masa remaja, remaja dalam masyarakat moderen seperti sekarang ini menghabiskan sebagian besar waktunya bersama dengan teman sebaya mereka.

Ristianti (2010) dari Tarakanita (2001) yang mengatakan bahwa, teman sebaya selain merupakan sumber referensi bagi remaja mengenai berbagai macam hal, juga dapat memberikan kesempatan bagi remaja untuk mengambil peran dan tanggung jawab yang baru melalui pemberian dorongan (dukungan sosial).

Pertemuan remaja dengan teman sebaya dapat dilakukan baik di sekolah melalui kegiatan-kegiatan seperti OSIS (Organisasi Intra Sekolah), dan UKS (Usaha Kesehatan Sekolah) yang terdapat di lingkungan sekolah SMP Negeri 1 Hinai, dan dapat juga di lingkungan masyarakat seperti perkumpulan remaja mesjid, karang taruna, dll, yang semua kegiatan tersebut berjalan baik di lingkungan kecamatan Hinai. Dengan banyaknya aktifitasaktifitas yang positif tersebut dapat membantu remaja dalam memperoleh teman yang mendukung dalam perilaku yang baik.

Namun, walaupun pada saat ini pengaruh teman sebaya masih kategori baik terhadap pembentukan asertifitas remaja, tidak menutup kemungkinan pengaruh tersebut berubah kearah yang tidak baik, sehingga tetap diperlukan pengawasan orang tua dalam memantau hubungan anak remaja dengan teman sebaya.

\section{DAFTAR PUSTAKA}

Albert, B., 2012, With One Voice 2012: Highlights from a Survey of Teens and Adults about Teen Pregnancy and Related Issues, The National Campaign to Prevent Teen and Unplanned Pregnancy.

Ali, M \& Asrori, M., 2011, Psikologi Remaja, Perkembangan Peserta Didik, Jakarta; Penerbit PT. Bumi Aksara

Badan Perencanaan Pembangunan Nasional, 2007, Kesehatan Reproduksi Remaja, PIK KRR, Jakarta.

Badan Pusat Statistik (BPS), 2012, Statistik Pemuda Indonesia 2011, Jakarta ; BPS

Badan Pusat Statistik (BPS), BKKBN, DEPKES RI, Macro Internasional, 2008, Youth Reproduction Health Survey 2007, Calverton, Maryland, USA : BPS dan Macro Internasional

Brown, A., Cooper, D., Getlin, R., Spotnitz, J., Tompkins, P., Wasson, E., 2009 Assertive Sexual Communication. Research Group Davis Honors Challenge Winter.

Department of Health and Human Service, 2012, National Youth Risk Behavior Survey (YRBS), Trends in the Prevalence of Sexual Behaviors and HIV Testing
National YRBS: 1991-2011, Centers for Disease Control and Prevention.

Dinas Kesehatan Kabupaten Langkat, 2012, Profil Kesehatan Kabupaten Langkat tahun 2011, Stabat

Hidayah, I., P.,2010, Pengaruh Asertivitas Terhadap Prilaku Seksual Pranikah Pada Remaja Perempuan. Skripsi, Fakultas Psikologi, Universitas Sumatera Utara

Marini, L., Andriani, E., 2005, Perbedaan Asertivitas Remaja Ditinjau Dari Pola Asuh Orang Tua, Jurnal Psikologia 1(2); 46-53; Program Studi Psikologi. Universitas Sumatera Utara.

Muadz, M. M., Syaefuddin., 2010, Keterampilan Hidup (Life Skills) dalam Program Penyiapan Kehidupan Berkeluarga bagi Remaja, Direktorat Remaja dan Perlindungan Hak-Hak Reproduksi, Jakarta. BKKBN

Myers \& Myers, 2002, The Dynamics Of Human Communication.New York, McGraw-Hill, Inc

Notoadmodjo,S., 2007 A, Kesehatan Masyarakat, Ilmu dan Seni, Jakarta ; Penerbit Rineka Cipta.

Rakos, F.A., 1991, Assertive Behavior ; Theory, Research, and training, Library of Congress Cataloging in Publication Data. New York

Ristianti, A., Hubungan Antara Dukungan Sosial Teman Sebaya dengan Identitas Diri Pada Remaja di SMA Pusaka 1 Jakarta

Rosita, H., 2011, Hubungan Antara Perilaku Asertif dengan Kepercayaan Diri Pada Mahasiswa, Skripsi. Fakultas Psikologi, Universitas Gunadarma. Jakarta

Santrock, J.W., 2007, Remaja, Edisi Kesebelas, Jakarta ; Penerbit Erlangga.

Sarwono, S.W.,2012, Psikologi Remaja, Edisi Revisi, Jakarta; Penerbit Rajawali Press.

Suwarjo, 2008, Konseling Teman Sebaya (Peer Counseling) Untuk Mengembangkan Resiliensi Remaja, Jurusan Psikologi Pendidikan dan Bimbingan Fakultas Ilmu Pendidikan, Universitas Pendidikan Indonesia

Suwarni, L., 2009, Monitoring Parental dan Perilaku Teman Sebaya Terhadap Perilaku Seksual Remaja SMA Di Kota Pontianak Jurnal Promosi Kesehatan Indonesia 4(2) : 127-130 ; Dinas Kesehatan Kota Pontianak Propinsi Kalimantan Barat.

Titanida, A., 2008, Hubungan Antara Pola Asuh Demokratis Orangtua dengan Tingkat Asertivitas Remaja. Skripsi, Program Studi Psikologi, Fakultas Psikologi Dan Ilmu Sosial, Budaya Universitas Islam Indonesia

World Health Organization, 2012, Preventing Early Pregnancy and Poor Reproductive Outcomes Among Adolescents in Developing Countries, WHO 